\title{
Studies on Preparation and Preservation of Squash from Wild Pomegranate (Punica granatum L.) Fruits and its Quality Evaluation During Storage
}

\author{
N. S. Thakur, G. S. Dhaygude, Abhimanyu Thakur*, Pradeep Kumar and Hamid
}

Dept. of Food Science and Technology, Dr Y.S.P. University of Horticulture and Forestry, Nauni, Solan, H.P. (173 230), India

\section{Corresponding Author}

Abhimanyu Thakur

e-mail: abhimanyuthakurprashar@gmail.com

\author{
Article History \\ Article ID: AR1856 \\ Received in $5^{\text {th }}$ January, 2018 \\ Received in revised form $19^{\text {th }}$ January, 2018 \\ Accepted in final form $1^{\text {st }}$ February, 2018
}

\begin{abstract}
Wild pomegranate fruit is a rich source of organic acids apart from having appreciable amount of sugars, anthocyanins, phenols, ascorbic acid and minerals like phosphorus, calcium, potassium, iron etc. The present studies were undertaken for the development of squash from wild pomegranate fruit and its quality evaluation during storage of six months. Different combinations of juice and sugar syrup/TSS (Total soluble solids) were tried to standardize proper combination for squash. The squash prepared by following the best selected recipe ( $42 \%$ juice and $45^{\circ} \mathrm{B}$ TSS) was packed in glass and PET (Polyethylene terephthalate) bottles and stored for six months under ambient and refrigerated temperature conditions. Squash could be safely stored for a period of six months under both the storage conditions without much change in various quality characteristics. Various physico-chemical characteristics increased/decreased like TSS (45 to $\left.45.68{ }^{\circ} \mathrm{B}\right)$,

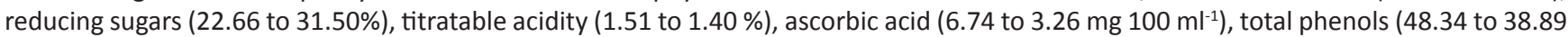

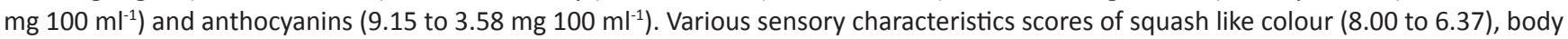
( 8.10 to 6.97 ), taste ( 8.10 to 6.97 ), aroma ( 8.20 to 6.57 ) and overall acceptability ( 8.05 to 6.39 ) decreased during storage. However, the changes in the quality characteristics of the squash were slower in refrigerated storage conditions as compared to ambient conditions. Both the packaging materials viz. PET and glass bottles were found suitable, with comparatively less changes occurring in glass bottles stored under refrigerated conditions.
\end{abstract}

Keywords: Wild pomegranate, Punica granatum, squash, polyethylene terephthalate, storage

\section{Introduction}

Wild pomegranate (Punica granatum L.), belongs to Punicaceae family and it is an important wild fruit of economic importance. Pomegranate is extensively cultivated in Spain, Egypt, Russia, France, Argentina, China, Japan and India besides its wild form is found in Syria, Afghanistan, Central Asia and India (Patil and Karade, 1996). In India it is found in sub mountainous and outer Himalayas of Himachal Pradesh, Jammu and Kashmir, and Uttaranchal, up to an elevation of $1800 \mathrm{~m}$ above mean sea level (Parmar and Kaushal, 1982; Saxena et al., 1987). In India, it is found in vast tract of the hill slopes of Himachal Pradesh, Jammu and Kashmir and Uttarakhand at an altitude of 900 to $1800 \mathrm{~m}$ above mean sea level. In Himachal Pradesh, it is distributed in some pockets of Solan, Sirmour, Mandi, Shimla, Kullu and Chamba districts.

The traditional importance of pomegranate as a medicinal plant is well established by various researchers. The edible part of the pomegranate fruit is arils, which are rich in sugars, organic acids, vitamins and bioactive compounds (Tehranifar et al., 2010). The fruit also contains good amount of minerals like phosphorus, calcium, potassium and iron (Parmar and Kaushal, 1982). Citric acid is present in sufficient quantity in this fruit besides, other acids like malic, succinic and tartaric acid. The unripe fruits and flowers are useful in inducing vomiting and the rind of the fruit is used for curing of diarrhoea and dysentery (Kirtikar and Basu, 1935). Extracts of tannins (bark, leaves and immature fruit) have been used to treat diarrhoea and haemorrhage, whereas, dried and crushed flower buds are made into tea as a remedy for bronchitis. Today pomegranate juice has been found to contain polyphenols (primarily ellagic and punicalagin) that may lower down the risk of heart diseases (Aviram et al., 2004) and slow down the cancer progress (Adams et al., 2006). Traditionally, wild pomegranate fruit is used for the preparation of dried arils (anardana) and used as a spice in Northern India (Kingsly et al., 2006). The use of cultivated pomegranate fruits for various value added products is well known. But only few reports are available for 
the development of various value added products out of wild pomegranate fruit. So keeping in view its nutritional value and increasing demand of value added products in modern era, the present study has been carried out to standardize the recipe for squash preparation along with its quality evaluation during storage.

\section{Materials and Methods}

\subsection{Raw material and extraction of juice}

Wild pomegranate fruits harvested at optimum maturity were procured from Narag area of Sirmour district of Himachal Pradesh during the year 2009-2010 and were used for physicochemical analysis and juice extraction. The juice from the fruit was extracted with help of food processor.

\subsection{Development of fruit squash}

Squashes were prepared by mixing the wild pomegranate juice and sugar syrup as per the different treatment combinations given in Table 1. To get the desirable concentration of acid $(1.50 \%)$ in squash, citric acid was added in all the treatment combinations. Sodium benzoate ( $600 \mathrm{ppm})$ was added in all the treatments as a preservative during product preparation. The squash prepared by following the best selected combination on the basis of sensory evaluation was packed in pre-sterilised glass and PET bottles (transparent bottles of $700 \mathrm{ml}$ capacity). All the packed products were properly labelled and stored at ambient $\left(20-25^{\circ} \mathrm{C}\right)$ and refrigerated $\left(4-7^{\circ} \mathrm{C}\right)$ conditions for six months. The physico-chemical and sensory characteristics of all the products were analyzed at 0, 3 and 6 months of storage.

Table 1: Treatment combinations of fruit squash

\begin{tabular}{llllllllllll}
\hline $\mathrm{T}_{1}$ & $\mathrm{~T}_{2}$ & $\mathrm{~T}_{3}$ & $\mathrm{~T}_{4}$ & $\mathrm{~T}_{5}$ & $\mathrm{~T}_{6}$ & $\mathrm{~T}_{7}$ & $\mathrm{~T}_{8}$ & $\mathrm{~T}_{9}$ & $\mathrm{~T}_{10}$ & $\mathrm{~T}_{11}$ & $\mathrm{~T}_{12}$ \\
\hline 30 & 35 & 40 & 42 & 30 & 35 & 40 & 42 & 30 & 35 & 40 & 42 \\
40 & 40 & 40 & 40 & 45 & 45 & 45 & 45 & 50 & 50 & 50 & 50 \\
\hline
\end{tabular}

\subsection{Physico-chemical analysis and sensory evaluation}

The colour of squash in terms of different units (Red and Yellow) was observed with Tintometer (Lovibond Tintometer Model-E). TSS, sugars, titratable acidity, ascorbic acid content and anthocyanins of squash were determined according to the standard procedures as described by Ranganna (2009). Total phenols content was determined by Folin-Ciocalteu procedure given by Singleton and Rossi (1965). Nine point hedonic rating test was followed for conducting the sensory evaluation of wild pomegranate squash. The panel of ten judges comprising of faculty members and students of department of Food Science and Technology, Dr Y S Parmar University of Horticulture and Forestry, Nauni, Solan (HP) were selected to evaluate the products for sensory parameters such as colour, body, taste, aroma and overall acceptability.

\subsection{Statistical analysis}

Data on physico-chemical characteristics of squash was analysed by Completely Randomized Design (CRD) before and during storage, whereas, data pertaining to the sensory evaluation were analyzed by using Randomized Block Design (RBD) as described by Mahony (1985). The experiment for recipe standardization was replicated three times and for storage studies five times.

\section{Results and Discussion}

\subsection{Standardization of recipe for the preparation of wild pomegranate squash}

The data pertaining to physico-chemical and sensory characteristics of wild pomegranate squash prepared by following different recipes are presented in Table 2 and 3.

\subsubsection{Physico-chemical characteristics}

Data in Table 2 reveal that visual red and yellow TCU of different recipes ranged between 9.24 to 15.90 and 1.08 to 2.40 , respectively. The maximum (15.90) red TCU were recorded in treatment combination having $42 \%$ juice and 45 ${ }^{\circ} \mathrm{B}$ TSS $\left(\mathrm{T}_{8}\right)$ which were statistically at par with $\mathrm{T}_{3}, \mathrm{~T}_{4}, \mathrm{~T}_{11}$ and $\mathrm{T}_{12}$ and minimum (9.24) were observed in treatment combination having $30 \%$ juice and $40{ }^{\circ} \mathrm{B}$ TSS $\left(\mathrm{T}_{1}\right)$ which were statistically at par with $\mathrm{T}_{5}$ and $\mathrm{T}_{9}$. Highest (2.40) yellow TCU were recorded in treatment combination having $30 \%$ juice and $40{ }^{\circ} \mathrm{B}$ TSS $\left(T_{1)}\right.$ and lowest (1.08) were observed in recipe containing 40 $\%$ juice and $50^{\circ} \mathrm{B}$ TSS $\left(T_{11}\right)$.

Further, the highest titratable acidity of squash was recorded in $\mathrm{T}_{4}, \mathrm{~T}_{8}$ and $\mathrm{T}_{12}$, whereas, lowest $(0.98 \%)$ was recorded in recipe containing $30 \%$ juice and $50{ }^{\circ} \mathrm{B}$ TSS $\left(\mathrm{T}_{9}\right)$. The ascorbic

Table 2: Physico-chemical characteristics of different recipes of wild pomegranate squash

\begin{tabular}{lcccccc}
\hline Treatments & \multicolumn{6}{c}{ Physico-chemical characteristics } \\
\cline { 2 - 6 } & $\begin{array}{c}\text { Co- } \\
\text { lour }\end{array}$ & (TCU) & TSS & TA & AA & pH \\
\cline { 2 - 5 } & $\left.{ }^{\circ} \mathrm{B}\right)$ & & & \\
\cline { 2 - 5 } $\mathrm{T}_{1}$ & 9.24 & 2.40 & 40.00 & 0.99 & 4.86 & 3.95 \\
$\mathrm{~T}_{2}$ & 11.92 & 2.10 & 40.00 & 1.20 & 5.63 & 3.91 \\
$\mathrm{~T}_{3}$ & 13.80 & 2.00 & 40.00 & 1.40 & 6.42 & 3.90 \\
$\mathrm{~T}_{4}$ & 15.65 & 1.10 & 40.00 & 1.51 & 6.72 & 3.89 \\
$\mathrm{~T}_{5}$ & 9.28 & 2.34 & 45.00 & 1.00 & 4.85 & 3.95 \\
$\mathrm{~T}_{6}$ & 11.94 & 2.14 & 45.00 & 1.20 & 5.67 & 3.91 \\
$\mathrm{~T}_{7}$ & 13.94 & 2.15 & 45.00 & 1.41 & 6.45 & 3.90 \\
$\mathrm{~T}_{8}$ & 15.90 & 1.15 & 45.00 & 1.51 & 6.74 & 3.90 \\
$\mathrm{~T}_{9}$ & 9.32 & 2.26 & 50.00 & 0.98 & 4.87 & 3.96 \\
$\mathrm{~T}_{10}$ & 12.00 & 2.17 & 50.00 & 1.21 & 5.67 & 3.91 \\
$\mathrm{~T}_{11}$ & 14.01 & 1.08 & 50.00 & 1.41 & 6.47 & 3.95 \\
$\mathrm{~T}_{12}$ & 15.82 & 1.15 & 50.00 & 1.51 & 6.78 & 3.88 \\
$\mathrm{CD}(p=0.05)$ & 2.10 & 0.15 & - & 0.02 & 0.42 & 0.01 \\
\hline
\end{tabular}

TA: Titratable acidity (\%); AA: Ascorbic acid (mg $\left.100 \mathrm{ml}^{-1}\right)$; 
acid content of different recipes ranged between 4.85 to $6.78 \mathrm{mg} / 100 \mathrm{ml}$. The maximum was recorded in treatment combination having $42 \%$ juice and $50{ }^{\circ} \mathrm{B}$ TSS $\left(\mathrm{T}_{12}\right)$ which was statistically at par with $T_{3}, T_{4}, T_{6}, T_{7}, T_{8}$ and $T_{11}$. However, minimum was observed in the recipe containing $30 \%$ juice and $45^{\circ} \mathrm{B}$ TSS $\left(\mathrm{T}_{5}\right)$. The $\mathrm{pH}$ value of various recipes varied from 3.88 to 3.96 .

\subsubsection{Sensory characteristics}

The data on sensory characteristics of different recipes of wild pomegranate squash has been given in Table 3. The colour

Table 3: Sensory characteristics (score) of different recipes of wild pomegranate squash

\begin{tabular}{lccccc}
\hline Treatments & Colour & Body & Taste & Aroma & $\begin{array}{c}\text { Overall ac- } \\
\text { ceptability }\end{array}$ \\
\hline $\mathrm{T}_{1}$ & 6.00 & 6.65 & 5.15 & 6.00 & 5.65 \\
$\mathrm{~T}_{2}$ & 6.40 & 6.80 & 6.00 & 6.50 & 5.85 \\
$\mathrm{~T}_{3}$ & 7.00 & 7.05 & 6.80 & 7.00 & 7.00 \\
$\mathrm{~T}_{4}$ & 7.30 & 7.65 & 7.45 & 7.10 & 7.55 \\
$\mathrm{~T}_{5}$ & 6.35 & 6.70 & 5.10 & 6.15 & 5.85 \\
$\mathrm{~T}_{6}$ & 6.50 & 6.90 & 6.15 & 6.25 & 5.75 \\
$\mathrm{~T}_{7}$ & 7.10 & 7.00 & 7.10 & 7.00 & 7.05 \\
$\mathrm{~T}_{8}$ & 8.00 & 8.10 & 8.10 & 8.20 & 8.05 \\
$\mathrm{~T}_{9}$ & 6.15 & 6.70 & 5.10 & 6.30 & 5.55 \\
$\mathrm{~T}_{10}$ & 6.80 & 6.85 & 6.00 & 6.60 & 5.90 \\
$\mathrm{~T}_{11}$ & 7.20 & 7.15 & 7.10 & 7.10 & 7.10 \\
$\mathrm{~T}_{12}$ & 7.75 & 7.20 & 7.35 & 7.00 & 7.05 \\
$\mathrm{CD}(p=0.05)$ & 0.53 & 0.57 & 0.54 & 0.52 & 0.47 \\
\hline
\end{tabular}

score ranged from 6.00 to 8.00 , the highest score was obtained in treatment combination having $42 \%$ juice and $45^{\circ} \mathrm{B}$ TSS $\left(\mathrm{T}_{8}\right)$ which was statistically at par with treatment combination having $42 \%$ juice and $50{ }^{\circ} \mathrm{B}$ TSS $\left(T_{12}\right)$, whereas, lowest was observed in recipe containing $30 \%$ juice and $40{ }^{\circ} \mathrm{B}$ TSS $\left(\mathrm{T}_{1}\right)$. The mean body score of this product ranged from 6.65 to 8.10 and among different recipes the same recipe $\left(\mathrm{T}_{8}\right)$ obtained the maximum body score which was statistically at par with $\mathrm{T}_{4}$ and the minimum was recorded in recipe containing $30 \%$ juice and $40^{\circ} \mathrm{B}$ TSS $\left(T_{1}\right)$. The taste score of the product ranged from 5.10 to 8.10. The highest score of this parameter was recorded in treatment combination having $42 \%$ juice and $45{ }^{\circ} \mathrm{B}$ TSS $\left(\mathrm{T}_{8}\right)$ while $T_{5}$ and $T_{9}$ got the lowest score. The aroma score was recorded highest in the same recipe $\left(T_{8}\right)$, whereas, minimum score was observed in recipe containing $30 \%$ juice and $40^{\circ} \mathrm{B}$ TSS $\left(T_{1}\right)$. The highest score (8.05) of overall acceptability was awarded to treatment combination having $42 \%$ juice and 45 ${ }^{\circ} \mathrm{B}$ TSS $\left(\mathrm{T}_{8}\right)$ while recipe with $30 \%$ juice and $50{ }^{\circ} \mathrm{B}$ TSS $\left(\mathrm{T}_{9}\right)$ got the lowest score of 5.55 .

From the above results it was concluded that recipe with 42 per cent juice and $45^{\circ} \mathrm{B}$ TSS $\left(\mathrm{T}_{8}\right)$ was the best on the basis of sensory and some physico-chemical characteristics of squash. This recipe obtained maximum scores for sensory parameters like colour, body, taste, aroma and overall acceptability which might be due to higher juice content, best combination of juice and syrup, best sugar-acid blend in the product and finally all these factors might have led the judges to award the highest scores to this recipe.

\subsection{Storage of wild pomegranate squash}

\subsubsection{Physico-chemical characteristics}

The red and yellow TCU (Tintometer Colour Units) of squash decreased significantly (Figure $1 \mathrm{a}$ and $1 \mathrm{~b}$ ) during storage. However, decrease was significantly lower under refrigerated storage conditions than ambient. The reason for decrease in colour units of squash during storage might be due to degradation of anthocyanins pigment. However, these pigments degraded at slower rate in low temperature hence, less decrease observed in refrigerated conditions. Nonsignificant difference among both the packaging materials shows their equal effect on colour of squash. Similar trend of decrease in red and yellow TCU has been reported by Thakur et al. (2016) in box myrtle appetizer, Thakur and Thakur (2017) in box myrtle squash and Hamid et al. (2017) in mulberry syrup.

The squash showed a slight decrease in titratable acidity during storage (Figure 1c) which was comparatively more under ambient conditions as compared to refrigerated conditions. However, with respect to packaging material this decrease was non-significant. The decrease in titratable acidity during storage might be due to co-polymerization of organic acids with sugars and amino acids (Selvamuthukumaran and Khanum, 2013). The TSS content of squash increased slightly during storage (Figure 1d) and this increase during storage might be due to partial hydrolysis of complex carbohydrates into monosaccharide and soluble disaccharides (Kannan and Thirumaran, 2002). More increase in TSS was found in squash stored under ambient conditions as compared to refrigerated storage conditions. Reducing and total sugars of squash (Figure 1e and 1f) showed a significant increase in storage which was comparatively less in refrigerated storage conditions than in ambient conditions. This increase might be due to hydrolysis of starch into sugars as well as conversion of complex polysaccharides into simple sugars and hydrolysis or inversion of non-reducing to reducing sugars. However, non-significant decrease among both the packaging materials shows their equal effect on sugar content of squash.

Ascorbic acid content of squash decreased significantly during storage however, the decrease was lower in refrigerated storage conditions than ambient (Figure 1g). The decrease in ascorbic acid content might be due to its degradation into dehydro-ascorbic acid or furfural during storage. A significant decrease in anthocyanins content of squash was recorded during the storage (Figure $1 \mathrm{~h}$ ) and more retention of anthocyanins was observed under refrigerated storage conditions than ambient conditions. Loss of anthocyanins 
in squash might be due to their high susceptibility to auto oxidative degradation (hydrolysis) during storage (Waskar and Khurdiya, 1987). A significant decrease in total phenols content of squash was recorded during storage (Figure $1 \mathrm{i}$ ) and their decrease was lower under refrigerated storage conditions than ambient conditions. The decrease in the total phenol content of squash during storage might be due to their involvement in the formation of polymeric compounds by complexing with protein and their subsequent precipitations as observed by Abers and Wrolstad (1979).

The changes in various physico-chemical characteristics during
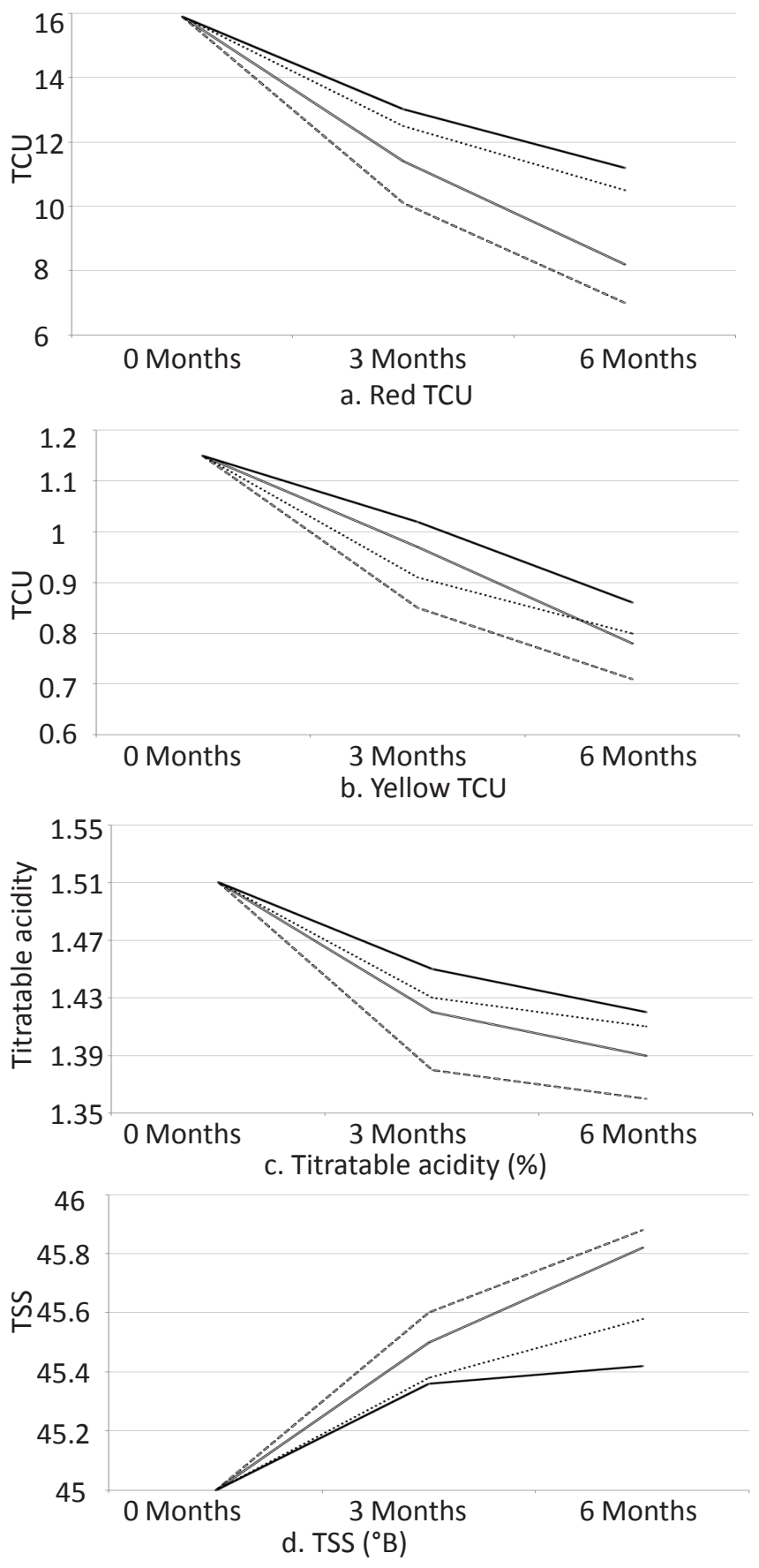
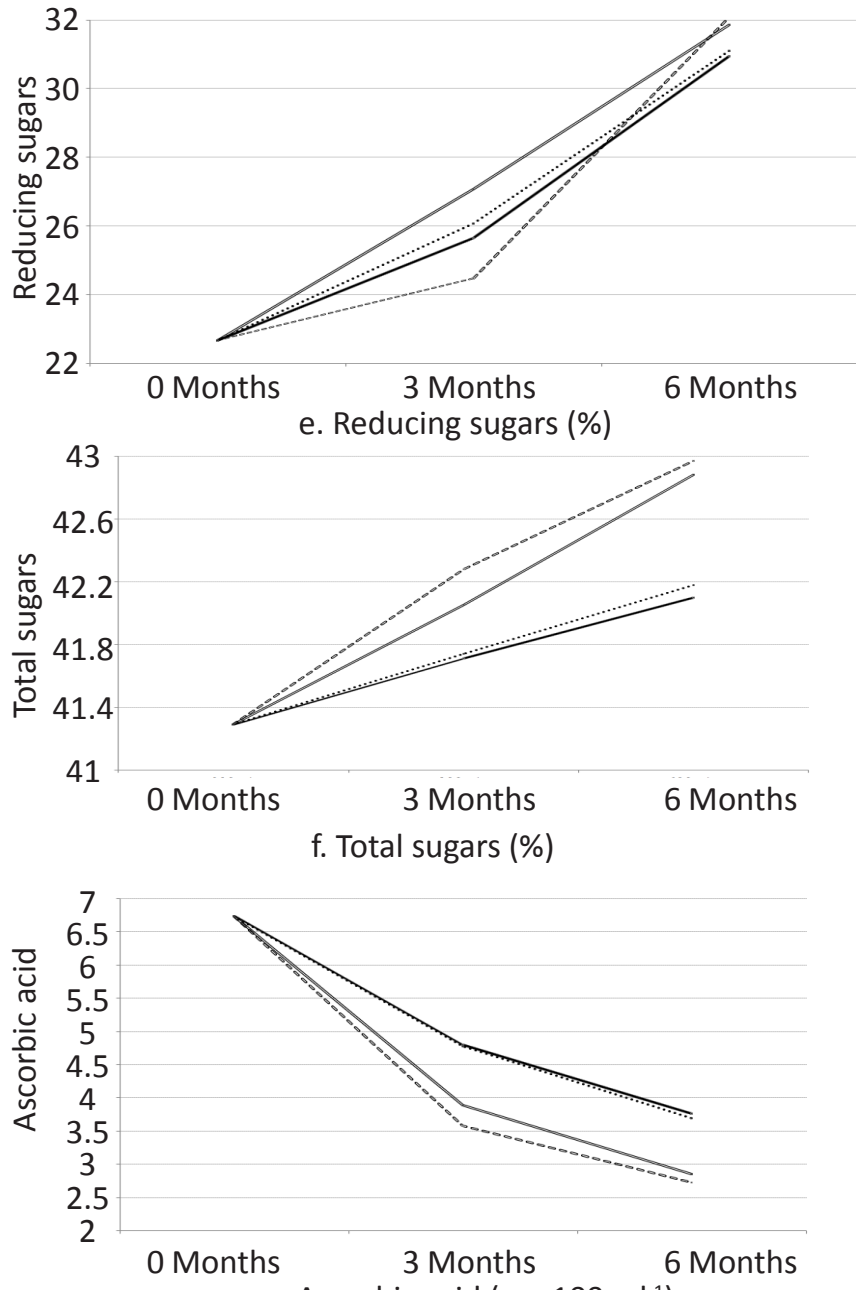

g. Ascorbic acid (mg $\left.100 \mathrm{ml}^{-1}\right)$

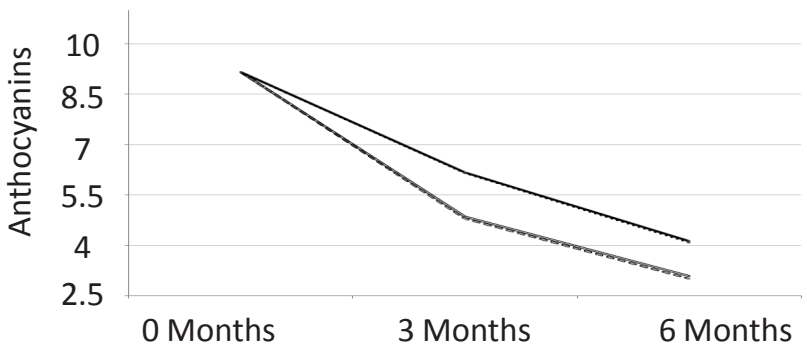

h. Anthocyanins (mg $100 \mathrm{ml}^{-1}$ )

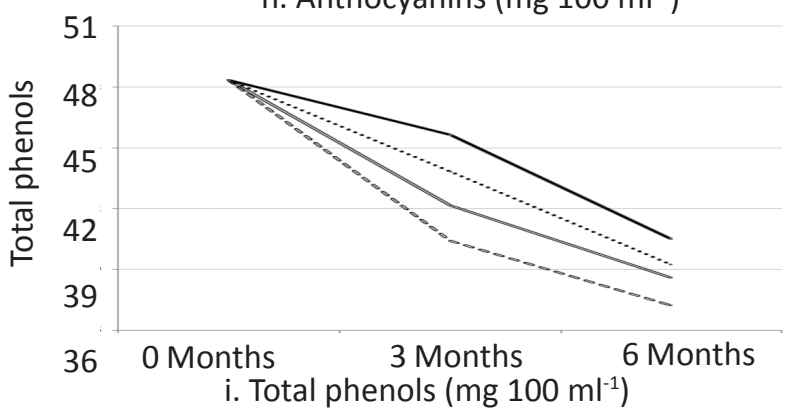

-Ambient glass :=:-: Ambient PET — Refrigerated glass Refrigerated PET

Figure 1: Effect of storage on physico-chemical characteristics of wild pomegranate squash 
storage were comparatively more under ambient conditions as compared to refrigerated storage conditions due to the faster rate of reaction as a result of high temperature in ambient conditions. As far as packaging material is concerned, fewer changes in physico-chemical characteristics of squash packed in glass bottles than PET bottles were observed which might be due to the difference in their thermal conductance properties which affect internal decomposition reactions. A similar trend for above said physico-chemical characteristics has been reported by Prasad and Mali (2000) and Shrinivas et al. (2007) in pomegranate squash.

\subsubsection{Sensory characteristics of wild pomegranate squash during storage}

The sensory characteristics scores of squash decreased significantly during storage (Figure 2-5) and this decrease was more pronounced under ambient storage conditions than refrigerated storage conditions. Retention of higher sensory scores in refrigerated conditions might be due to the better condition of the squash during storage as a result of slower rate of chemical reactions. Decrease in colour scores during storage might be due to degradation of colour pigment (anthocyanins) and browning caused by co-polymerization of organic acids of the product and this might have led the judges to award the lower scores during storage. The possible reason for decrease in body scores might be due to the formation of precipitates in the product as a result of interactions between phenols and protein as well as the formation of cation complexes with phenols during storage. The possible reason for decrease

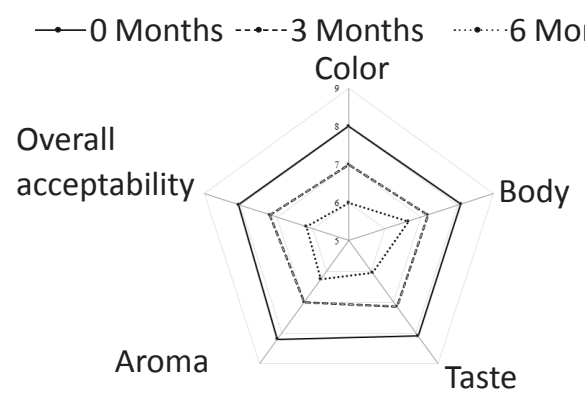

Figure 2: Effect of storage on sensory characteristics of wild pomegranate squash packed in PET bottles stored under ambient conditions

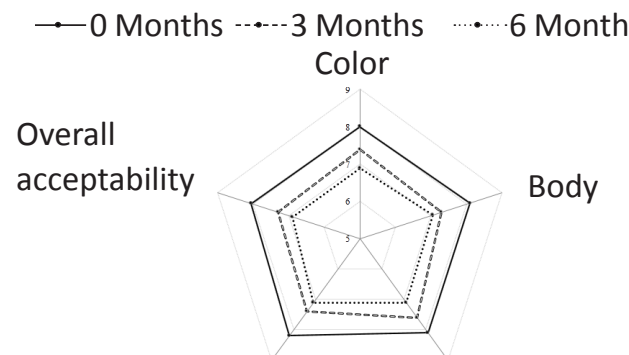

Aroma Taste

Figure 3: Effect of storage on sensory characteristics of wild pomegranate squash packed in glass bottles stored under ambient conditions

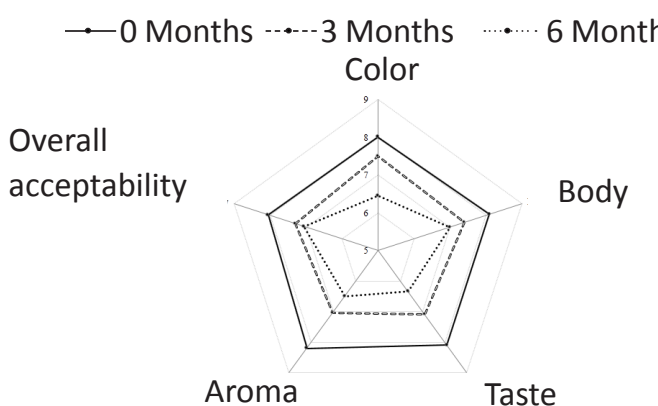

Figure 4: Effect of storage on sensory characteristics of wild pomegranate squash packed in PET bottles stored under refrigerated conditions

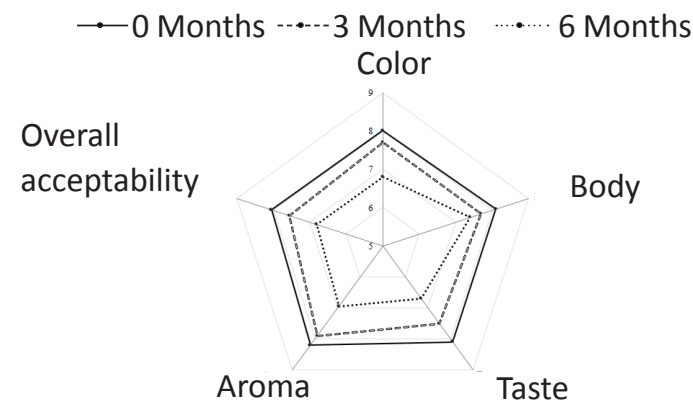

Figure 5: Effect of storage on sensory characteristics of wild pomegranate squash packed in glass bottles stored under refrigerated conditions

in taste scores might be due to the loss of sugar-acid blend responsible for taste during storage. The decrease in aroma scores during storage might be due to degradation of aromatic compounds in the product (Thakur and Barwal, 1998). There was a decrease in overall acceptability scores of squash during storage, which might be due to the loss in appearance, flavour compounds and uniformity of the product. Squash packed in glass bottles retained more sensory scores than PET bottles. The retention of better overall sensory scores of squash in glass bottles might be due to the better retention of above given factors as a result of slower reaction rate in glass bottles as compared to PET. The results were in conformity with the finding of Prasad and Mali (2000) and Shrinivas et al. (2007) in pomegranate squash.

\section{Conclusion}

The recipe with $42 \%$ juice and $45^{\circ} \mathrm{B}$ TSS $\left(\mathrm{T}_{8}\right)$ was the best on the basis of sensory characteristics of the squash. Squash could be stored safely for a period of six months under both storage conditions and also in both packaging materials with minimum changes in chemical and sensory attributes. However, comparatively fewer changes in squash packed in glass bottle and stored under refrigerated storage conditions were observed as compared to PET bottle.

\section{References}

Abers, J.E., Wrolstad, R.E., 1979. Causative factors of colour determination in strawberry preserves during processing 
and storage. Journal of Food Science and Technology $44,75-81$.

Adams, L.S., Seeram, N.P., Aggarwal, B.B., Takada, Y., Sand, D., Heber, D., 2006. Pomegranate juice, total pomegranate ellagitannins, and punicalagin suppress inflammatory cell signaling in colon cancer cells. Journal of Agricultural and Food Chemistry 54, 980-985.

Aviram, M., Rosenblat, M., Gaitini, D., Nitecki, S., Hoffman, A., Dornfeld, L., Volkova, N., Presser, D., Attias, J., Liker, H., Hayek, T., 2004. Pomegranate juice consumption for 3 years by patients with carotid artery stenosis reduces common carotid intima-media thickness, blood pressure and LDL oxidation. Clinical Nutrition 23, 423-433.

Hamid, Thakur, N.S., Kumar, P., Thakur, A., 2017. Development of syrup from mulberry (Morus alba L.) and its quality evaluation under ambient and refrigerated storage conditions. International Journal of Bio-resource and Stress Management 8(1), 116-121.

Kannan, S., Thirumaran, A.S., 2002. Studies on storage behaviour of jamun products. Beverage and Food World 29(3), 32-33.

Kingsly, A.R.P., Singh, D.B., Manikantam M.R., Jain, R.K., 2006. Moisture dependent physical properties of dried pomegranate seeds (Anardana) Journal of Food Engineering 75(4), 492-496.

Kirtikar, K.R., Basu, B.D., 1935. Indian Medicinal Plants. Lalit Mohan Basu, Dehradun, 1084.

Mahony, M.O., 1985. Sensory Evaluation of Food: statistical methods and procedures. Marcel Dekker, New York, 168-169.

Parmar, C., Kaushal, M.K., 1982. Wild Fruit of Sub-himalayan Region. Kalayani Publisher, New Delhi, 136.

Patil, A.V., Karade, A.R., 1996. Pomegranate. In: Bose TK and Mitra SK (Eds.), Fruits: tropical and sub-tropical. Naya Prakash, Calcutta, 617-631.

Prasad, R.N., Mali, P.C., 2000. Changes in physico-chemical characteristics of pomegranate squash during storage. Indian Journal of Horticulture 57, 18-20.
Ranganna, S., 2009. Handbook of Analysis and Quality Control for Fruit and Vegetable Products. Tata McGraw Hill, New Delhi, 1112.

Saxena, A.K., Manan, J.K., Berry, S.K., 1987. Pomegranate: post harvest technology, chemistry and processing. Indian Food Packer 41, 43-60.

Selvamuthukumaran, M., Khanum, F., 2013. Development of spiced seabuckthorn [Elaeagnus rhamnoides (L.) A. Nelson syn. Hippophae rhamnoides L.] mixed fruit squash. Indian Journal of Traditional Knowledge 13(1), 132-141.

Shrinivas, K.N., Revanna, M.L., Jamuna, K.V., 2007. Standardization of recipes for production of squash in pomegranate cultivar Ganesh and Mridulla. Journal of Dairy Food and Home Science 26(2), 133-136.

Singelton, V.L., Rossi, J.A., 1965. Colorimetry of total phenolics with phosphomolybdic phosphotungstic acid reagent. American Journal of Enology and Viticulture 16, 144-158.

Tehranifar, A., Zarei, M., Nemati, Z., Esfandiyari, B., Vazifeshenas, M.R., 2010. Investigation of physico-chemical properties and antioxidant activity of twenty Iranian pomegranate (Punica granatum L.) cultivars. Scientia Horticulturae 126(2), 180-185.

Thakur, K.S., Barwal, V.S., 1998. Studies on preparation and evaluation of squash from unmarketable kiwi fruit. Indian Food Packer 52, 26-27.

Thakur, N.S., Thakur, A., 2017. Development of squash from box myrtle (Myrica nagi) and its quality evaluation during storage. Journal of Hill Agriculture 8(1), 87-92.

Thakur, N.S., Thakur, A., Joshi, V.K., 2016. Development of appetizer from box myrtle (Myrica nagi) and its quality evaluation during storage. International Journal of Food and Fermentation Technology, 6(1), 151-161.

Waskar, D.P., Khurdiya, D.S., 1987. Effect of packaging containers on the anthocyanins of phalsa syrup. Indian Food Packer 41(5), 17-23. 